\title{
Research Article \\ Causes of Occupational Changes among Dalit Communities of Kaski District
}

\author{
${ }^{1}$ Amin Palikhe*, ${ }^{2}$ Netra Prasad Subedi, ${ }^{3}$ Hari Bahadur Bhandari, \\ ${ }^{4}$ Nabin Bahadur Adhikari \\ ${ }^{1}$ Lecturer, Faculty of Management, Prithvi Narayan Campus, Pokhara \\ ${ }^{2}$ Lecturer, Janapriya Multiple Campus, Faculty of Management, Pokhara, Nepal \\ ${ }^{3}$ Lecturer, Faculty of Management, Prithvi Narayan Campus, Pokhara \\ ${ }^{4}$ Lecturer, Faculty of Management, Prithvi Narayan Campus, Pokhara \\ *Corresponding Email: azpalikhe@yahoo.com
}

\begin{tabular}{c} 
Article History \\
Received 27 April $2021 \quad$ Revised 29 September $2021 \quad$ Accepted 21 November 2021 \\
\hline
\end{tabular}

\begin{abstract}
Occupational change from traditionally adopted occupations to new occupations is an increasing trend in the new generation of Nepalese society. And this seems relatively high in the people of Dalit communities. This study aims to investigate the status of occupational change and their causes among the Dalit communities of the Kaski district. This study has conducted by using the quantitative nature of data collected from primary sources with the help of a structured questionnaire. Total 300 head of the household covering 150 from each urban and rural area including 50 each from three Dalit caste groups namely Nepali (Sarki), Pariyar (Damai), and Bishowkarma (Kami) are the sample for this study. The information regarding the occupational change was collected from the head of the household. The study reveals that there is a statistically significant difference in the involvement in a particular occupation in the past and at present. The tendency of abandoning past \& caste-based occupation and shifting to new \& modern occupation is high (63.33\%) among the people of the Dalit communities. While investigating towards causes for occupational change; insufficient for livelihood, low return compares to costs \& efforts, lack of skills \& knowledge of past occupations, skills \& knowledge of other occupations, lack of work for a whole year in traditional occupations, have found as the key causes for the occupational change in the Dalit communities. However, 36.67 percent still involved in past occupations, and the key causes for no change in the past
\end{abstract}

(C) The Author, published by JRCC, Janapriya Multiple Campus. 
occupations are lack of other skill \& knowledge, satisfaction in the past occupation, and lack of capital.

Keywords: Caste, change, communities, Dalit, occupation, past, traditional

\section{INTRODUCTION}

The theory of occupational reconstructions emphasizes the mind-body engagement to deal with an inherently transformational injustice or problematic situation. This theory views occupations as pragmatic with meaning of inquiry. In other words, occupations are experiments for searching the truth. Occupations are creative, and engagement in occupations are intrinsically motivated (the hallmark of occupational therapy). This theory consists of seven principles, 1) Occupational reconstructions respond to a problematic situation; 2) Occupations have meaning and purpose to ameliorate the situation; 3) Occupations are comprised of embodied practices ; 4) Occupations have a narrative structure; 5) Occupations open up spaces for creative transform actions; 6) Occupations involve voluntary participation (i.e., emphasizing choice and freedom or action that is intrinsically motivated); and 7) Occupations are hopeful experiments. These principles aim to provide guidelines for therapists in studying, designing and evaluating small to large scale social transformation, including communitybased practice, community development, participation and inclusion, empowerment, health activism, occupational injustice, and political practices, by viewing occupations as both means and ends in changing situations of injustice (i.e., social transformation) (Frank \& Muriithi, 2015)

Since, Nepal is an agricultural country, the most common traditional occupation of people living in the country is farming. Besides that, it is characterized as a multi-ethnic, multi-linguistic, multi-religious, multi-cultural, and divergent typographical country (An Introduction to Nepal, 2020). The caste system is the basic foundation of Hindu society which is closely associated with the division of occupations according to the caste of the people. The caste system is based on the Varna system. Nepalese social structure is based on the Varna system, where different caste groups and individuals interact and are interdependent upon each other and their occupations. The caste or Varna system is based on four primary social classifications. These are the Brahmins (Priests, guru etc.), the Kshatriyas (Warriors, kings, administrators etc.), the Vaishya (agriculturalists, traders), and the Sudra (Laborers) (Joshi, 2017). 
The castes are exclusively based on occupations and are hereditary. In the caste hierarchy, the groups of people commonly known today as Dalits occupy the lowest rung. The term, 'Dalit', is generally used to identify those on the lowest rung in the caste hierarchy. In most writings, the term is also used to identify the vulnerable and poor groups of people who are oppressed, suppressed and exploited. The nomenclature, 'Dalit', was chosen by Dalit activists in India, rejecting other more widely accepted terms, for example untouchable, scheduled castes, depressed classes or Gandhi term, 'harijan' (meaning God's people). These developments in India influenced Nepalese activists. Nepalese Dalits, thus, increasingly reject the terms, 'achhut' (untouchable), 'sano jaat' (low caste), 'paani nachalne jaat' (water unacceptable castes), etc, and instead find their true identity in the term, Dalit (ILO, 2005).

Dalits have been relegated to do caste-based work as black/goldsmith, tailors, shoemakers and street cleaners, all are considered of low social status. Poverty and lack of other means of livelihood force the Dalits to continue their traditional occupations. Dalit women and children are also forced to work in the households of their landlords. They do not get justifiable wage for their labor. If they do not work for others, they work as help of their husbands in the traditional jobs of Dalits. Those working in Haliya Pratha (bonded labor) or Khala Pratha (forced labor) are not even earning from their work. They may get food grains. Lack of modern technology skills and financial resources prevent them from getting employed in new industries or trade in the market. Dalits who change from traditional occupation to wage labor do not therefore necessarily improve their economic conditions (Shrestha, 2002).

According to census of 2011 four geographical regions of Nepal, viz mountains, hills, inner terai and terai, Dalits are found in almost all hill districts, whereas mountain districts have sparser Dalit population. The Dalit population is higher in the hill and mountain regions combined (72.84\%) than in the terai and inner terai combined $(27.16 \%)$. The hills and mountains Dalit including Kami, Damai, and Sarki occupies 7.95 percent of total population of Nepal (CBS, 2012). The hills and mountains Sarki writes Nepali, Kami writes Bishowkarma and Damai writes Pariyar as surname for their identity.

Traditionally each caste group was specific occupations. However, some occupations also have been found adopted by more than a single caste. In hilly and mountain area the most common traditional occupations of the Bishowkarma are blacksmith, coppersmith, goldsmith work, and wooden-pot making. Tailoring, playing a musical instrument (Panche Baja), dancing, entertaining, and singing are the traditional occupation of Pariyar caste group and cobbler, leather related works, and wooden related works are the traditional occupation of 
Nepali caste group (ILO, 2005).

With the industrial revolution, the artisanal mode of production was considered too slow, sometimes even crude, and relegated to the margins as mechanised mass production took centre stage. Over the last three centuries, mechanisation has forced artisans to abandon their traditional livelihoods and join the pool of agricultural labour in a tumultuous process of de-industrialisation, which continues today. Ironically, it was a combination of capital and technology, along with artisanal skills and knowledge, which made the industrial revolution possible (Green, 2002). However, the United Nations estimates that in the last 30 years, the number of artisans in India alone has dropped by 30\% (Bouchart, 1993).

In recent times there is a rapid occupational shift in Dalit communities. The major causes for the occupational mobility issues among the Kami include socio-cultural practices, modernization, industrialization, urbanization, and widespread use of the western education system (Chetry, 2010).

Traditional Skill Technology (TST) of the Dalits was found on the verge of extinction barring some skills. In the majority of households, there is not a single member who knows about TST, which shows a decline of TST among the Dalits in the study area. But there is a remarkable intergroup variation. The Knowledge of TST is very poor among the Nepali group but it is far better among the Pariyars. It also shows that transfer of traditional occupational skills is very limited among the Nepali and high among the Pariyars. Two major TSTs of Dalits, such as ironwork and leatherwork, which are traditionally tied to Bishowkarma and Nepali groups respectively, are rapidly disappearing. The factory-produced commodities have been replacing the handmade traditional goods with a high price. Sewing or tailoring is the widely known TST of Pariyars. Pariyars are the only group that has maintained the knowledge of the traditional occupation. This is also because the sewing skill is still in demand in the market. The study clearly indicates that younger generations from Dalit groups are no longer interested in learning these TSTs. It can be said that knowledge about Dalit TSTs is gradually disappearing (Parajuli, 2012).

Although the major traditional occupations such as metalwork, tailoring, leatherwork, and sweeping, cleaning, and waste disposal are still associated particularly with Dalit caste groups, 42 percent of the respondents were still engaged in such occupations on a parttime basis only. This means that Dalit groups are gradually diversifying into non-traditional avenues, mainly to agricultural wage labour. Such occupational mobility among castes such as Damai, Kami, and Sarki/Chamar is largely due to the encroachment of modern factory- 
produced goods and the traditional non-cash mode of the transaction (Dalit NGO Federation, 2002).

Traditional occupations are still a key source of income, or aspect of daily livelihood subsistence, for many indigenous peoples and local communities. They also play an important role in the cultural, spiritual, religious, and medicinal aspects of community well-being. The occupations practiced are extremely varied: some are very specialized and practiced by few; others are widely practiced; it is common for various practices to be combined with other (traditional) activities; and men and women sometimes have different, complementary, roles and knowledge of traditional occupations. The occupations are tailored to and based on the natural environments where the communities live and have developed over generations as sophisticated knowledge-based practice systems (Forest Peoples Programme, 2016).

An investigation of causal factors for occupational variation between father and son using Nepalese data from rural context revealed that three fifths of all sons adopted occupations different than their fathers. Statistics test also revealed a statistically significant relationship between occupation of father and occupation of son. It is also found that sons of the fathers holding salaried job/business and trades as well as those having wage labour are more likely to catch father's occupation than the sons of farmers. Among all explanatory measures, sons' own level of education and migration experiences are powerful determinant for whether son adopts occupations different than their fathers or not (Aryal, Devkota, \& Devkota, 2019).

Whatsoever the situation of occupational caste, especially of Dalit caste group, in the past time, the traditional occupations, skills, and technology have significant value in recent time in terms of earnings and cultural identity. But the studies show that the youth of Dalit communities have been abandoning their traditional occupations and losing their skill, technology, and cultural identity. Investigating the status of occupational involvement in the past and at present time, the structure of occupational changes, and causes for the occupational shift in the Dalit communities are the major concern of this study. The main objective of this study is to assess the occupational change of Dalit communities. In addition, the following hypotheses were formulated.

The following are the research hypothesis for statistical test:

$\mathbf{H}_{\mathbf{1}}$ : $\quad$ There is statistically significant difference in the involvement in a particular occupation in the past and at present.

$\mathbf{H}_{2}$ : $\quad$ There is statistically significant different in the involvement in caste-based traditional occupations and new occupations. 
$\mathbf{H}_{3}$ : There is a statistically significant association between the Dalit caste groups and the nature of occupational changes.

\section{DATA AND METHODS}

In the past, the people of Dalit communities were exploited and discriminated against from the social, economic, and political perspectives. But, it also seems that they have been given a place in every society to take help of their skill base works. Every society seems to be benefited from the skill base works of these communities. There is no doubt; modernization of traditional occupations with modern technologies and equipment might be a good source of income. And the people of these communities could make their life more managed and comfortable. But, in the recent period, with the changes in the political, economic, and technological environment, the trend of abandoning traditional occupations seems to be increasing in the people of the Dalit communities. Therefore, investigating the status and causes of occupation change in people of Dalit communities according to the place of residence has become an interest of the researcher in this paper.

This study is conducted in Kaski. The Kaski District lies in the Gandaki province of Nepal and covers an area of 2,017 $\mathrm{km}^{2}$. A large part of this district falls in the hill area, it lies from the lowest point of 450 meters to the highest point of 8091 meters. This district has politically divided into a metropolitan city namely Pokhara and four village municipals namely Madhi, Rupakot, Machhapuchhre, and Annapurna.

To empirically investigate the identified research questions, this study adopted a descriptive cum analytical research design. In this study quantitative nature of data collected from primary sources has been used. The primary data have been collected through a selfadministrated structured questionnaire from resident of rural and urban areas of the Kaski district. The information regarding the past occupations (i.e. adopted by respondent's father) and present occupations (i.e. presently adopted by the respondent) and causes for occupational change was collected from the head of the household at the time of the survey. The questionnaire contains closed-ended, single and multiple-choice, and Likert-type questionnaires. This study has adopted the judgmental and quota sampling technique. The total sample size of the study is 300 household comprising 150 from each urban and rural area. And from each area, 50 household data have been used for each Dalit caste group namely; Nepali, Pariyar, and Bishwokarma. The collected data have been processed through SPSS version 26. In order to arrive at a finding of the research questions, appropriate descriptive and inferential statistical 
tools have been used. As per a general rule of thumb to conduct a pilot test on a survey on 30 to 100 participants (SAGE Publication Inc., 2016), a pilot survey conducted on 30 people in the Dalit communities. After conducting the pilot survey necessary amendments made in the questionnaire and on the methodology to increase the reliability and validity.

\section{RESULTS AND DISCUSSION}

\section{Caste and Place of Residence}

Table 1 presents the respondent profile based on the Dalit caste groups and their residential areas. Altogether 300 head of the families are the sample of this study. Each urban and rural areas covers equal percentage (50\%) of respondents. And each area includes 50 respondents from each Nepali, Pariyar, and Bishwokarma caste groups which accounting to 33.33 percent.

\section{Table 1}

Respondents Classified According to the Place of Residence

\begin{tabular}{lllll}
\hline Caste & Area & & Total & Percent \\
& Urban & Rural & & \\
\hline Nepali & 50 & 50 & 100 & 33.33 \\
Pariyar & 50 & 50 & 100 & 33.33 \\
Bishowkarma & 50 & 50 & 100 & 33.33 \\
Total & 150 & 150 & 300 & 100 \\
\hline
\end{tabular}

Source: Field Survey, 2020

\section{Caste and Literacy}

Table 2 presents the literacy level of respondents. It shows that there are 26 percent respondents have a basic level of literacy, 24.67 percent each are illiterate and literate, 19.67 percent are of secondary level and five percent are higher level of literacy.

\section{Table 2}

Caste and Literacy of Respondents

$$
\text { Literacy }
$$

Caste

Illiterate Literate

Basic Level Secondary Higher

Total

\begin{tabular}{lllllll} 
& \multicolumn{5}{c}{ Level } \\
\hline Nepali & 25 & 25 & 22 & 20 & 8 & 100 \\
Pariyar & 28 & 28 & 21 & 19 & 4 & 100
\end{tabular}




\begin{tabular}{lllllll} 
Bishowkarma & 21 & 21 & 35 & 20 & 3 & 100 \\
\hline Total & 74 & 74 & 78 & 59 & 15 & 300 \\
Percent & 24.67 & 24.67 & 26.00 & 19.67 & 5.00 & 100 \\
\hline
\end{tabular}

Source: Field Survey, 2020

\section{Changes in Occupational Involvement in the Past and at Present}

Table 3 presents the status of occupational involvement in the past and at present. Past occupation refers to that occupation which was adopted by the parent of the respondent and current occupation refers to that occupation which is presently adopted by the respondent. The study identify that there was an involvement in 17 types of occupations. The data indicates that there was the largest number of involvement in agriculture occupation accounting to 36 percent in the past followed by tailoring and playing Panche Baja (13.67\%), farming Labour $(13.67 \%)$, iron metal work and blacksmith $(9 \%)$, foreign employment $(8.33 \%)$, carpenter $(6 \%)$ and size of involvement in other new occupation were insignificance. Presently, the occupational involvement and the volume reveals different results.

\section{Table 3}

Occupational Involvement in the Past and at Present

\begin{tabular}{llllll}
\hline Occupation & $\begin{array}{l}\text { Involvement } \\
\text { in past }\end{array}$ & Percent (\%) & $\begin{array}{l}\text { Involvement } \\
\text { at present }\end{array}$ & $\begin{array}{l}\text { Percent } \\
(\%)\end{array}$ & Change \\
\hline $\begin{array}{l}\text { Tailoring and playing } \\
\text { panchi baja }\end{array}$ & 41 & 13.67 & 44 & 14.67 & 3 \\
Farming labour & 41 & 13.67 & 22 & 7.33 & -19 \\
Industry labour & 0 & 0.00 & 4 & 1.33 & 4 \\
Contractor & 1 & 0.33 & 3 & 1.00 & 2 \\
Agriculture & 108 & 36.00 & 32 & 10.67 & -76 \\
Iron metal_blacksmith & 27 & 9.00 & 9 & 3.00 & -18 \\
Goldsmith & 10 & 3.33 & 5 & 1.67 & -5 \\
Transport related job & 3 & 1.00 & 27 & 9.00 & 24 \\
Teaching & 3 & 1.00 & 8 & 2.67 & 5 \\
Foreign employment & 25 & 8.33 & 48 & 16.00 & 23 \\
Defense force & 8 & 2.67 & 4 & 1.33 & -4 \\
Carpenter & 18 & 6.00 & 21 & 7.00 & 3
\end{tabular}




\begin{tabular}{llllll} 
Trade and business & 4 & 1.33 & 31 & 10.33 & 27 \\
\hline Tourism Related Job & 1 & 0.33 & 8 & 2.67 & 7 \\
Private Sector Job & 1 & 0.33 & 1 & 0.33 & 0 \\
Govt. Sector Job & 9 & 3.00 & 28 & 9.33 & 19 \\
Others & 0 & 0.00 & 5 & 1.67 & 5 \\
Total & 300 & 100.00 & 300 & 100.00 & \\
\hline
\end{tabular}

Source: Field Survey, 2020

At present, majority of respondents' involvement is in foreign employment accounting to 16 percent followed by tailoring and Panche Baja (14.67\%), agriculture (10.67\%), trade and business (10.33\%), government job (9.33\%), farming labour (7.33\%), and carpenter (7\%). This data reveals that there is significant decline in parent occupation to respondent's current occupation especially in agriculture, farming labor, and Iron-metal work and blacksmith. However, there is noticeable growth in trade and business, transport related jobs, foreign employment, and government jobs respectively from past to present.

\section{Involvement in Traditional and New Occupations}

Table 4 presents occupational change from caste base traditional occupation to new occupation. Since, agriculture is a common type of occupation of Nepalese people as being agricultural country, it has presented separately. The data shows that 45.67 percent were involved in caste based occupation but this involvement decline to 33.67 percent at present and it is a decline of 26.28 percent from past to present. There was 18.33 percent involvement in new occupation in the past but this has increased to 55.67 percent. It an increase of 166 percent from past to present. Likewise there was a 36 percent involvement in agriculture as a farmer which decline to 10.67 percent at present, and it a decline of 70.37 percent from past to present. This facts indicate that there is significant tendency of leaving caste-base traditional occupations and farming and shifting to new types of occupations in the Dalit communities. 


\section{Table 4}

Occupational Involvement in Traditional and New Occupations

\begin{tabular}{|c|c|c|c|c|c|c|}
\hline $\begin{array}{l}\text { Type of } \\
\text { Occupation }\end{array}$ & Occupations & 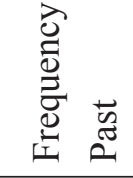 & $a^{\circ}$ & 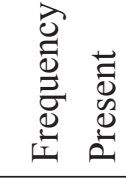 & $\partial^{\circ}$ & 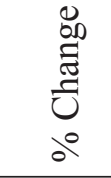 \\
\hline $\begin{array}{l}\text { Caste-based } \\
\text { Traditional } \\
\text { Occupation }\end{array}$ & $\begin{array}{l}\text { Tailoring, Musician } \\
\text { (Panche Baja), Ironsmith, } \\
\text { Coppersmith, Goldsmith, } \\
\text { Carpenter, Farming labor }\end{array}$ & 137 & $45.67 \%$ & 101 & 33.67 & -26.28 \\
\hline $\begin{array}{l}\text { Common } \\
\text { Occupation }\end{array}$ & Agriculture/ Farmer & 108 & $36.00 \%$ & 32 & 10.67 & -70.37 \\
\hline $\begin{array}{l}\text { New } \\
\text { occupation }\end{array}$ & $\begin{array}{l}\text { Industry Labour, Transport } \\
\text { Related Jobs, Teaching, } \\
\text { Defense Force, Trade and } \\
\text { Business, Tourism Related } \\
\text { Job, Private Sector Job, } \\
\text { Govt. Sector Job, others } \\
\text { Total }\end{array}$ & 300 & $18.33 \%$ & 167 & 55.67 & 166 \\
\hline
\end{tabular}

Source: Field Survey, 2020

\section{Occupational Change}

Table 6 presents the occupational change in the Dalit caste groups. The states of change has been categorized into no change (i.e. carrying the same past occupations), partial change (i.e. involvement in past as well as new occupation), and complete change (i.e. completely abended the past occupations). The data reveals there is 50 percent completely change in the past occupation followed by 27 percent do not change, and 23 percent partially change. In Pariyar caste group 52 percent completely change in the past occupation followed by 41 percent do not change and only 7 percent change partially. Likewise in Bishwokarma caste group 42 percent do not change the previous occupation, followed by 37 percent completely change and 21 percent change in the past occupation partially. In aggregate the figure of complete change in the past occupation is the largest accounting for 46.33 percent followed by 36.67 percent do not change the past occupation, and 17 percent do partial change in the past occupations. 
Table 6

Nature of Occupational Change Status Based on Caste

\begin{tabular}{lllll}
\hline Caste & No Change & $\begin{array}{l}\text { Partially } \\
\text { Change }\end{array}$ & Completely Change & Total \\
\hline Nepali & 27 & 23 & 50 & 100 \\
Pariyar & 41 & 7 & 52 & 100 \\
Bishwokarma & 42 & 21 & 37 & 100 \\
Total & 110 & 51 & 139 & 300 \\
Percent & 36.67 & 17.00 & 46.33 & \\
\hline
\end{tabular}

Source: Field Survey, 2020

A chi-square test has been conducted to examine the statistical relationship between caste and nature of occupational change at significant level of 0.05. The Pearson Chi-Square statics is 15.641 with $d f=4$, and $p=0.04$. The $p$ value is less than 0.05 (i.e. $p<0.05$ ), it is a sufficient evidence to explain that there is a statistically significant association between caste and nature of occupational change situation. Similarly, the Phi and Cramer's V value of 0.228 indicates a very strong association between caste and nature of occupational change situation, and it is significant as well.

\section{Causes of occupational Change}

To identify the key causes for different nature of occupational change in the people of the Dalit communities, data has been collected from multiple choice questions, and the data has been rank based on respondents' responses.

\section{Causes for no Change in Previous Occupation}

Table 7 presents 20.65 percent respondents do not change their past occupation due to lack of other skills and knowledge followed by satisfaction with the past occupation accounting for 15.81 percent, the third key cause for no change in the previous occupation is due to lack of capital (15.48\%), and the fourth key cause for no change in occupation is sufficient for livelihood (13.23\%). The other causes have been ranked accordingly in table 9 .

Table 7

Causes for no change of Past Occupation

\begin{tabular}{llll}
\hline Causes & Frequency & Percent & Rank \\
\hline Lack of other skills and knowledge & 64 & 20.65 & 1 \\
Satisfaction with the previous occupation & 49 & 15.81 & 2 \\
\hline
\end{tabular}




\begin{tabular}{llll}
\hline Lack of capital & 48 & 15.48 & 3 \\
Sufficient for livelihood & 41 & 13.23 & 4 \\
Good source of income & 29 & 9.35 & 5 \\
Preserve the previous occupation and culture & 24 & 7.74 & 6 \\
Other partial income sources & 22 & 7.1 & 7 \\
Possibility of modernization & 16 & 5.16 & 8 \\
Fear of financial risk & 11 & 3.55 & 9 \\
Fear of social contempt & 6 & 1.94 & 10 \\
Total & 310 & 100 & \\
\hline
\end{tabular}

Source: Field Survey, 2020

\section{Causes for Partial Change of Occupation}

Table 9 presents the causes for a partial change in the past occupation. The four key causes for a partial change in the past occupation are; not sufficient for livelihood (33.56\%), skills \& knowledge of other occupation (20.13\%), lack of work for the whole year (18.79\%), and availability of other sources of income (17.45\%) respectively. The other causes have been rank in table 10 accordingly.

\section{Table 8}

Causes for a Partial Change of the Past Occupation

\begin{tabular}{llll}
\hline Causes & Frequency & Percent & Rank \\
\hline Not sufficient for livelihood & 50 & 33.56 & 1 \\
Skill \& knowledge of other occupation & 30 & 20.13 & 2 \\
Lack of work for whole year & 28 & 18.79 & 3 \\
Availability of other sources of income & 26 & 17.45 & 4 \\
Social circumstance & 10 & 6.71 & 5 \\
Pressure of family member & 3 & 2.01 & 6 \\
Others & 2 & 1.34 & 7 \\
Total & 149 & 100 & \\
\hline
\end{tabular}

Source: Field Survey, 2020

\section{Causes for Complete Change of the Previous Occupation}

Table 10 presents causes for a complete change in the previous occupation. The four key 
causes for a complete change in the past occupation are; not sufficient for livelihood (30.61\%), low return compare to cost \& effort (15.05\%), lack of skills \& knowledge (14.03\%), and lack of helping hands $(9.69 \%)$ respectively.

\section{Table 9}

Causes for Complete Change in the Previous Occupation

\begin{tabular}{lccc}
\hline Causes & Frequency & Percent & Rank \\
\hline Not sufficient for livelihood & 120 & 30.61 & 1 \\
Low return compare to cost \& effort & 59 & 15.05 & 2 \\
Lack of skills and knowledge & 55 & 14.03 & 3 \\
Lack of helping hands & 38 & 9.69 & 4 \\
Other & 33 & 8.42 & 5 \\
Lack of modern technology & 30 & 7.65 & 6 \\
Caste based discrimination/no respect & 30 & 7.65 & 7 \\
Climate change & 10 & 2.55 & 8 \\
Lack of raw materials & 9 & 2.3 & 9 \\
Lack of market for products & 8 & 2.04 & 10 \\
Total & 392 & 100 & \\
\hline
\end{tabular}

Source: Field Survey, 2020

\section{CONCLUSION}

Changes have been observed in the involvement in a particular occupation in the past and at present. There is an increasing tendency of leaving traditional \& caste-based occupations and shifting to new \& modern types of occupation in the new generation of Dalit communities in Kaski district. The result depicted that about half of people of the Dalit communities have changed their past occupations completely and shifted to a new occupation and this figure reaches 63.33 percent if we combined it with the figure of a partial change in the past occupation. However, there is also difference among the Dalit caste groups and the nature of occupational changes. Insufficiency for livelihood, low return compare to costs \& effort, lack of skill and knowledge in the traditional occupations are the three key causes for a complete change in the past occupations. Similarly, insufficiency for livelihood, skill \& knowledge of other occupations, and lack of work for the whole year are three key causes for a partial change in the past occupations. 


\section{REFERENCES}

DoIB (2020), An Introduction to Nepal. Department of Information and Broadcasting, Government of Nepal. Retrieved from http://www.doinepal.gov.np

Aryal, B., Devkota, D., \& Devkota, N. R. (2019, December). Inter-generation mobility in occupations of people in rural Nepal. Janapriya Journal of Interdisciplinary Studies, 8, 25-39.

Bouchart, D. (1993). Preliminary study on the status ofcCraftworkers. UNESCO.

CBS. (2012). National population and housingcCensus 2011. Central Bureau of Statistics.

Chetry, D. B. (2010). Changing occupation pattern among the Bishwokarmas: A case study of Hemja VDC. Himalayan Journal of Sociology and Antropology, IV, 49-60.

DNF. (2002). Caste-based prejudic and distcrimination in Nepal. Danida/HUGOU by the Dalit NGO Federation of Nepal. DNF.

Forest Peoples Programme. (2016). Status and trend in traditional occupations: Outcomes of a rapid assessment. Stratford Road, England: Forest peoples programme. Retrieved from Forest Peoples Programme: https://www.forestpeoples.org/en/topics/conventionbiological-diversity-cbd/publication/2016/status-and-trends-traditional-occupation

Frank, G. B., \& Muriithi, B. K. (2015). Theorising social transformation in occupational science: The American civil rights movement and South African truggle against apartheid as 'occupaiona reconstructions'. South African Journal of Occupational Therapy, 11-19.

Green, K. (2002). A rough trade: How artisan ironworkers mediated architectural modernism. A case study of early steel-framed architecture, the 1897 Wesleyan Church, Darwin. Paper presented at the Additions to Architectural History, XIXth Conference of the Society of Architectural Historians. Australia and New Zealand.

ILO. (2005). Dalits and Labour in Nepal: Discrimination and Forced Labour. International Labour Organization.

Joshi, N. (2017, November 20). Caste system in ancient India. World history Encyclopedia. Retrieved from https://www.worldhistory.org/article/1152/caste-system-in-ancient-india/

Parajuli, B. K. (2012). Knowledge and practice of traditional skill technology among Hill Dalit of Kaski: A study based on Pariyar, Nepali and Bishowkarma of Kaski District. Himalayan Journal of Sociology \& Antropology, V, 19-33.

SAGE Publicaiton, Inc. (2016). Pretesting and pilot testing. Retrieved from https://www. sagepub.com/sites/default/files/upm-binaries/68507_Ruel_Chapter_6.pdf

Shrestha, A. (2002). Dalits in Nepal: Story of discrimination. Retrieved from AssianPacific Human Rights Information Centre: https://www.hurights.or.jp/archives/focus/ section2/2002/12/dalits-in-nepal-story-of-discrimination.html. 